\title{
Vena Cava Filters are not Superior to Low Molecular Weight Heparin in Venous Thromboembolism Prophylaxis: A Study on Long-Term Immobilized Neurosurgical Patients
}

\author{
Vena Kava Filtreleri Venöz Tromboembolizm Profilaksisinde Düşïk \\ Molekül Ăgırlılı Heparine Üstün Değildir: Uzun Süre Mobilize \\ Olmayan Nöroşirürji Hastaları Üzerinde Yapılan Bir Çallş̧ma
}

Ilkay AKMANGIT ${ }^{1}$, Ergun DAGLIOGLU², Sadik Ahmet UYANIK $^{1}$, Baris AHLAT ${ }^{1}$, Fatih ALAGOZ ${ }^{2}$, Ibrahim EKICI ${ }^{2}$, Dogan DEDE ${ }^{1}$, Ahmet Deniz BELEN ${ }^{2}$

${ }^{1}$ Ankara Numune Education and Research Hospital, Radiology Clinics, Ankara, Turkey

${ }^{2}$ Ankara Numune Education and Research Hospital, Neurosurgery Clinics, Ankara, Turkey

Corresponding Author: Ergun DAGLIOGLU / E-mail: edaglioglu@gmail.com

\begin{abstract}
AIM: Deep venous thrombosis (DVT) and pulmonary embolism (PE) are the most frequent surgical problems and associated with high morbidity and mortality. Neurosurgical patients constitute a unique group where prophylaxis with anticoagulant and antiaggregant agents are relatively contraindicated due to the natural course of vascular problems such as aneurysms, hemorrhagic tumors or hematomas or increased vulnerability to complex spinal surgeries and trauma.

MATERIAL and METHODS: We included 67 patients predicted to be immobilized for 2 or more months in this retrospective analysis. A vena cava filter was inserted between the first and seventh postoperative day in 40 patients in a prophylactic manner whereas 27 patients received low dose heparin for the same purpose. The patients were evaluated for symptomatic DVT or PE.

RESULTS: Percutaneous insertion was performed for all filters without any complication. DVT occurred in two patients of the filter group and 1 patient of the heparin group. There was no PE recorded in any patient of either group. Patients were followed up for 22 months in the filter and 16 months in the heparin group.

CONCLUSION: We conclude that prophylactic filter use in high risk neurosurgical patients is not beneficial and not superior to low-molecularweight heparin use. Nevertheless, it is reasonable to prevent PE in patients with proven DVT who have no contraindication for anticoagulant drugs.
\end{abstract}

KEYWORDS: Deep venous thrombosis, Venous thromboembolism, Vena cava filter, Low molecular weight heparin, Pulmoner embolism prophylaxis, Neurosurgical patients

öz

AMAÇ: Derin ven trombozu ve pulmoner embolizm yüksek morbidite ve mortaliteyle seyreden en sık cerrahi problemler arasında yer alır. Anevrizma gibi vasküler problemler, hemorajik tümörler, hematom, kompleks spinal cerrahi ve travma gibi nöroşirürjiye ait hastalıklar antiagregan ve antikoagülan tedavinin göreceli olarak kontrendike olduğu özel bir grubu oluşturmaktadır.

YÖNTEM ve GEREÇLER: Bu retrospektif çalışmada, 2 ay veya daha uzun süre immobilize olması beklenen 67 hastanın analizi yapılmıştır. Vena kava filtreleri 40 hastada postoperatif bir ile yedinci günde proflaktik amaçla yerleştirildi. 27 hastada ise aynı amaçla düşük moleküler ağırlıklı heparin kullanıldı. Hastalar yattıkları süreçte ve izlemde semptomatik derin ven trombozu (DVT) ve pulmoner emboli (PE) açısından takip edildi.

BULGULAR: Bütün filtreler perkütan yolla yerleştirildi ve işleme ait herhangi bir komplikasyon gelişmedi. Filtre grubunda 2, heparin grubunda 1 hastada DVT gelişti. Her iki grupta PE saptanmadı. Hastalar filtre grubunda ortalama 22 ay, heparin grubunda 16 ay süreyle takip edildi.

SONUÇ: Yüksek riskli nöroşirürji hastalarında prolaktik filtre kullanımının düşük moleküler ağırlıklı heparin kullanımına üstün olmadığı düşünüldü. Buna rağmen DVT'si kanıtlanmış ve antikoagülan ilaçların kontrendike olduğu durumlarda PE'yi önlemede etkin olduğu açıktır.

ANAHTAR SÖZCÜKLER: Derin ven trombozu, Venöz tromboz, Vena kava filtresi, Düşük molekül ağırlıklı heparin, Pulmoner emboli profilaksi, Nöroşirürjikal hastalar 


\section{INTRODUCTION}

Deep venous thrombosis (DVT) and pulmonary embolism (PE) are frequently encountered in surgical patients and associated with high morbidity and mortality during hospitalization. Patients with neurosurgical problems constitute a unique group since these patients need strict control of hemorrhage risk in the perioperative period. Complex spinal surgeries for patients with severe neurological deficits may be associated with long-term immobilization and some brain tumors are associated with hypercoagulability. Hamilton et al stated that incidence of DVT in a high risk group of neurosurgical patients was $18-50 \%$ while that of PE was $0-25 \%$ (13). Moreover, neurosurgical patients presenting with cerebral aneurysm, arteriovenous malformation, hemorrhagic tumor and trauma form the most challenging group and are at higher risk. Given the possibility of a surgical intervention, it is questionable to use an antiaggregant and anticoagulant agent for DVT and PE prophylaxis due to high risk of bleeding. Pharmacological agents might result in catastrophic complications in the peri- and postoperative period and their use is therefore not considered to be beneficial $(1,6,7,23,18,19)$. Although absolute and relative indications of vena cava filters are still debatable, their prophylactic use in patients with neurosurgical problems has not been reported thoroughly in the literature $(8,10,20,22,24,26,28)$.

Conventional practice includes use of elastic bandage, surgical stockings or intermittent pneumatic compression. Pharmacological prophylaxis with lowered dose low molecular weight heparin is reported to be a safer alternative but the use of these agents might also be hazardous $(1,6,7,23)$. Vena cava filters (VCF) offer an alternative-adjuvant treatment option for prevention of the pulmonary embolism in high risk patient groups where pharmacological prophylaxis is risky or contraindicated $(1,4,26)$. The PREPIC study showed that VCF is effective in preventing PE (26). Current indications of VCF include patients with acute VTE or DVT who cannot receive anticoagulation or in whom adequate anticoagulation has clearly failed to prevent recurrent VTE.

In a clinical setting, two thirds of placed VCF were reported to be permanent filters instead of retrievable filters (32). Retrievable inferior vena cava filters (IVCFs) were designed to provide temporary protection from pulmonary embolism in high-risk situations and short-term surgeries. Several reports pointed to their questionable influence in protection of VTE and danger of permanently implanted filters that lead to potential complications. Severe complications, some of which can be fatal, have been reported with IVC filters: filter strut fracture, filter migration/embolization, IVC or aortic penetration, and thrombotic complications $(5,33)$. The incidence of these complications varies depending on the series. Nevertheless, the use of IVC filters has been increasing even in the setting of prophylactic use without evidence of PE or DVT $(30,31)$. VCF has no effect on thrombus formation or lysis of the existing thrombus. VCF prevents PE by trapping the thrombus and preventing its migration to the pulmonary vasculature.
In the present study, we present our experience on vena cava filters in the prevention of PE compared to subcutaneous low molecular weight heparin in a group of patients with neurosurgical problems.

\section{MATERIAL and METHODS}

A total of 67 patients who underwent spinal surgery and craniotomy due to intracranial tumor or tumor-like masses were included in the study. In this retrospective study, the patients were considered to have a high risk for thromboembolism due to prolonged immobilization in the postoperative period and a debilitated status. Patients with a history of documented DVT or PE were excluded. Patients operated at the Neurosurgery Clinics of Ankara Numune Education and Research hospital between March 2010 and March 2013 were analyzed. Patients predicted to be immobilized for at least 2 or more months in accordance with the postoperative clinical status (severe postoperative deficits) were included. There were 32 male and 35 female patients. The mean age of the patients was 51.8 (range 23 to 82 ) years. All patients used an elastic bandage or surgical stockings at the perioperative period. The mean duration of hospital stay after implantation was 4.3 days.

The Vena-Tech ${ }^{T M}$ LP vena cava filter (B. Braun Interventional Systems Med. Inc., PA. USA) was the only preferred type for insertion. Vena cava filters were placed at Interventional Radiology clinics of Ankara Numune Education and Research Hospital by two interventional radiologists. All patients were operated by the same neurosurgeon. On the other hand, patients who received low molecular weight heparin were operated by another neurosurgeon. The vena cava filter was inserted between the first and seventh postoperative day in 40 patients in a prophylactic manner before discharge whereas 27 patients received low dose heparin for the same purpose (Table I, II).

On clinical follow-up, lower extremity Doppler ultrasonography and pulmonary $\mathrm{CT}$ angiography were performed for cases with suspected DVT and PE. Patients in the filter group were followed up for 22 months on average after discharge for complications regarding DVT, PE and status of VCF. Patients in the heparin group were followed up for 16 months on average and evaluated for symptomatic DVT or PE.

\section{RESULTS}

All filters were inserted percutaneously under ultrasound and fluoroscopy guidance. The right femoral route was selected in all patients and filters were placed into IVC inferior to the renal vein origin successfully in all patients. There was no periprocedural complication.

Seven patients in filter group died due to heart failure, sepsis, and intracranial hemorrhage during hospitalization but no death or surgical site hemorrhages were recorded in subcutaneous heparin group. Since there was no randomization, an inevitable tendency towards VCF use was present in patients with major systemic problems. 
Table I: The Age and Sex Distribution of Patients are Summarized in Table I. The p Value Between the Two Groups was Estimated as 0.714

\begin{tabular}{|l|c|c|}
\hline Patient Profile & Vena cava filter & Low molecular weight heparin \\
\hline Male & 18 & 14 \\
\hline Female & 22 & 13 \\
\hline Age Range & $24-82$ & $23-69$ \\
\hline Mean Age & 55.6 & 46.2 \\
\hline
\end{tabular}

Table II: Clinical Characteristics of the Study Population Including Diagnosis and Surgical Procedure

\begin{tabular}{|c|c|c|c|}
\hline \multicolumn{2}{|l|}{ Diagnostic profile } & Vena Cava Filter & Low molecular weight heparin \\
\hline \multirow{4}{*}{ Complex spinal surgery } & Spinal tumor & 7 & 5 \\
\hline & Spinal stenosis & 3 & 5 \\
\hline & Vertebral fracture & 9 & 4 \\
\hline & Spinal abscess & 4 & 2 \\
\hline \multirow{3}{*}{ Craniotomy } & Glial tumor & 7 & 6 \\
\hline & Posterior fossa tumor & 3 & 3 \\
\hline & Other* & 7 & 2 \\
\hline \multicolumn{2}{|l|}{ Total } & 40 & 27 \\
\hline
\end{tabular}

*Diagnoses included meningioma, cerebellopontine angle tumor, sellar macroadenoma, craniopharyngioma and intraventricular tumor.

Furthermore there is no statistical age difference between two groups with a $p$ value of 0.714 (mean age of 55.6 versus 46.2 years), which is insignificant.

DVT occurred in one patient and was confirmed by ultrasonography during hospitalization. PE was not observed in any of the patients from either group. Patients were followed up for 22 months on average after discharge. Two more patients in the filter group died during the follow-up period due to underlying malignancy. One patient was diagnosed with a developed DVT at the first month of follow-up. No PE was reported in patients of filter group on follow-up.

In the heparin group one patient was diagnosed with DVT during hospitalization and again there was no PE. Patients were followed for 16 months on average after discharge. No symptomatic DVT or PE was observed during follow-up.

\section{DISCUSSION}

Venous thromboembolism is a frequently encountered complication in neurosurgical patients and associated with high morbidity and mortality. In the present study, patients with brain tumors and spinal disorders who were immobilized due to postoperative severe deficits for more than 2 predicted months were included.

Benign or malignant brain tumors, spinal cord injury, head trauma, stroke, prolonged surgery or immobilization are well known risk factors for developing DVT and PE (17). It is also well known that long postoperative immobilization period after surgery is considered to be risky for DVT. Patients with gliomas are considered to be in the high risk group since gliomas secrete several tissue factors that activate coagulation cascades. In addition, tissue damage to the brain as a consequence of craniotomy, chemotherapy or radiotherapy results in hypercoagulability (29). In a retrospective study by Khaldi et al. on patients hospitalized in the Intensive Care Unit (ICU), the incidence of DVT was reported to be $84 \%$ within one week in a separate group of high risk neurosurgical ICU patients and an additional $8 \%$ within two weeks in high risk patients with neurosurgical pathologies (17). Since DVT is strongly associated with PE, these patients are also at risk of PE. PE rates reported in the literature differ from $1.5 \%$ to $5 \%$ with a mortality rate of $9 \%$ to $50 \%$ (2). In the present study there was a slight tendency to use VCF as a prophylactic measure in high risk neurosurgical patients with associated systemic problems.

An increased preference to use filters more in patients with severe systemic problems might have resulted in increased mortality of VCF group. Marked predisposition to use VCF in high risk neurosurgical patients resulted in increased mortality in the filter group but this does not signify that these deaths were due to VCF, neurological sequelae or related complications. This predisposition was probably caused by the awareness of the surgeon about the risks of a permanent filter (25-27).

Several studies have focused on PE and DVT due to its preventable nature. Mechanical methods such as compression stockings, intermittent compression devices and early mobilization are widely used and reported to reduce the incidence of DVT and PE $(6,11,21)$. Mechanical prophylaxis assisted by the use of heparin or low-molecular weight heparin further reduces the incidence of these conditions. However, pharmacological prophylaxis may cause 
hemorrhagic complications that might result in catastrophic outcomes. There seems to be a lack of consensus on the use of pharmacological prophylaxis. Some authors suggest pharmacological prophylaxis to be safe $(12,17)$ while there are reports that indicate the risk of hemorrhage is higher (1, $6,7,14)$.

Vena cava implantation has been the preferred method of prophylaxis for VTE in the last decades. Ease of implantation and elimination of the need for anticoagulation at the postoperative risky period have increased usage by physicians. However, vena cava implantation may be associated with complications during implantation despite image guidance or due to the filter itself on follow-up. The incidence of complications is lower with the new generation of vena cava filters with their low profile and ease of application. However, complications such as filter migration, vena cava perforation, and vena cava thrombosis are still reported. The incidence of complications is reported to be $0-69 \%$ in the literature (25-27). In the present study, all filters were inserted on a permanent basis. Retrieval of filters is also reported to be associated with a high risk of complications. It was considered that a late attempt to remove filters from the patients might lead to further complications since patients included in the study had severe neurological deficits.

It is reported that filter complications are dependent upon the duration of the presence of the filter in the vascular system and that the complications will be reduced after the removal of the filter following the DVT-PE risk period. In the present study, all filters seemed to be well tolerated by the patients on follow-up compared to the literature, which might be due to lack of DVT and PE at the time of insertion. Retrievable filters provide the interventionist a further option for removal but all filters were of the permanent type in the present study due to predicted long term neurological deficits. There is an increased tendency to use optional filters in recent years since they may be removed percutaneously within the period specified by the manufacturer. Retrieval of IVC filters might be complicated in patients with longer filter indwelling times (9), and IVC penetration of filter struts may prevent successful retrieval 2 weeks after implantation (3). It should be noted that removal might be unsuccessful due to technical problems or the presence of thrombus on the filter itself.

The prophylactic use of vena cava filters for prevention of PE is still challenging. American College of Chest Physicians advocate the use of vena cava filters in cases with proven DVT and anticoagulation contraindicated or unsuccessful, however Society of Interventional Radiology points to prophylactic use for patients with high risk DVT and PE in addition to the above indications $(15,16)$. There is not any randomized controlled study in the literature concerning the prophylactic use of vena cava filters in neurosurgical pathologies. The majority of prophylactic based studies are retrospective case series of patients with complex spinal surgery. In a clinical study including 219 patients by McClendon et al, DVT was reported in 36 patients $(18.7 \%)$ and $P E$ in 8 patients (3.7\%). All vena cava filters were implanted for prophylactic purposes and filters were noted to decrease PE significantly compared to control group (22). In the same study VCF indications were limited to hypercoagulability, prolonged immobilization, staged procedures of longer than 5 segment levels, combined anterior-posterior approaches, iliocaval manipulation during exposure, and anesthetic time of more than 8 hours excluding the patients with a history of DVT or PE. Ozturk et al reported a significant decrease in PE risk in their study on 129 patients with similar characteristics (24). In the literature, there are case series, performed on a lower number of patients, pointing to the use of vena cava filters in patients subjected to complex spinal surgery as a safe and effective method in preventing PE $(8,20,28)$. In the present study, pulmonary embolism was not reported in both groups. Although total number of patients in this study is relatively insufficient to make a general conclusion, it might be concluded that VCFs do not provide further protection compared to primary prophylaxis with subcutaneous heparin.

Studies on prophylactic use of vena cava filters among neurosurgical patients excluding spinal surgery group are rather limited. In their retrospective study, Ghanim et al compared the effects of anticoagulation and VCF on hospital and overall mortality rate in 175 patients with intracranial malignancy and intracranial hemorrhage. The data obtained in this study was not considered to be statistically significant although it was determined that VCF had a reduction of $64 \%$ in hospital and $28 \%$ on overall mortality (10). In our study there is a slight favor towards low molecular weight heparin compared to filter usage that points to high efficiency of low molecular weight heparin.

The major limitations of the present study are the limited number of patients and heterogeneous patient population. All patients received mechanical prophylaxis and number of patients in each group is not equal. Two patients in filter group developed DVT during hospitalization or on follow-up and one patient from low molecular weight heparin group developed DVT on follow-up. As none of the patients in both groups developed PE during hospitalization and on followup statistically comparison of VCF and heparin efficacy in preventing PE is not applicable.

It is difficult to advocate the prophylactic indication of VCF for routine clinical practice due to limited number of studies and absence of randomized clinical trials. Though it appears an effective method of prophylaxis in selected patients, VCF should be cautiously used for routine prophylactic manner when findings of this study are considered.

\section{REFERENCES}

1. Agnelli G: Prevention of venous thromboembolism in surgical patients. Circulation 110:IV4-IV12, 2004

2. Agnelli G, Piovella F, Buoncristiani $P$, Severi $P$, Pini $M, D^{\prime}$ Angelo A, Beltrametti C, Damiani M, Andrioli GC, Pugliese R, lorio A, Brambilla G: Enoxaparin plus compression stockings alone in the prevention of venous thromboembolism after elective neurosurgery. N Eng J Med 359:80-85, 1998 
3. Ashley DW, Mix JW, Christie B, Burton CG, Lochner FK, McCommon GW, Matoy GC, Solis MM, Donner RS, Dalton ML, Tyson CS, Newman WH: Removal of the OptEase retrievable vena cava filter is not feasible after extended time periods because of filter protrusion through the vena cava. J Trauma 59:847-852, 2005

4. Chiou AC, Biggs KL, Matsumura JS: Vena cava filters: Why, when, what, how? Perspect Vasc Surg Endovasc Ther 17(4):329-339, 2005

5. Cipolla J, Weger NS, Sharma R, Schrag SP, Sarani B, Truitt $M$, Lorenzo M, Sims CA, Kim PK, Torigian D, Temple-Lykens B, Sicoutris CP, Stawicki SP: Complications of vena cava filters: $A$ comprehensive clinical review. OPUS 12 Scientist 2(2):11-24, 2008

6. Collen JF, Jackson JL, Shorr AF, Moores LK: Prevention of venous thromboembolism in neurosurgery: A metaanalysis. Chest 134(2):237-249, 2008

7. Danish SF, Burnett MG, Ong JG, Sonnad SS, MaloneyWilensky E, Stein SC: Prophylaxis for deep venous thrombosis in craniotomy patients: A decision analysis. Neurosurgery 56(6):1286-1292, 2005

8. Dazley JM, Wain R, Vellinga RM, Cohen B, Agulnick MA: Prophylactic inferior vena cava filters prevent pulmonary embolisms in high-risk patients undergoing major spinal surgery. J Spinal Disord Tech 25(4):190-195, 2012

9. Dinglasan LA, Oh JC, Schmitt JE, Trerotola SO, Shlansky-Goldberg RD, Stavropoulos SW: Complicated inferior vena cava filter retrievals: Associated factors identified at preretrieval CT. Radiology 266:347-354, 2013

10. Ghanim AJ, Daskalakis C, Eschelman DJ, Kraft WK: A five-year, retrospective, comparison review of survival in neurosurgical patients diagnosed with venous thromboembolism and treated with either inferior vena cava filters or anticoagulants. J Thromb Thrombolysis 24(3):247-254, 2007

11. Goldhaber SZ, Dunn K, Gerhard-Herman M, Park JK, Black PM: Low rate of venous thromboembolism after craniotomy for brain tumor using multimodality prophylaxis. Chest 122:1933-1937, 2002

12. Hacker RI, Ritter G, Nelson C, Knobel D, Gupta R, Hopkins K, Marini CP, Barrera R: Subcutaneous heparin does not increase postoperative complications in neurosurgical patients: An institutional experience. J Crit Care 27(3):250-254, 2012

13. Hamilton MG, Hull RD, Pieno GF: Venous thromboembolism in neurosurgery and neurology patients: A review. Neurosurgery 34(2):280-296, 1994

14. Hamilton MG, Yee WH, Hull RD, Ghali WA: Venous thromboembolism prophylaxis in patients undergoing cranial neurosurgery: A systematic review and meta-analysis. Neurosurgery 68:571-581, 2011

15. Hircsh J, Guyatt G, Albers GW, Harrington R, Schumemann HJ: American College of Chest Physicians' evidence-based clinical practice guidelines. Chest 133(6 Suppl):71S-109S, 2008
16. Kaufman JA, Kinney TB, Streiff $M B$, Sing $R F$, Proctor $M C$, Becker D, Cipolle M, Comerota AJ, Millward SF, Rogers FB, Sacks D, Venbrux AC: Guidelines for the use of retrievable and convertible vena cava filters: Report from the Society of Interventional Radiology multidisciplinary consensus conference. J Vasc Interv Radiol 17: 449-459, 2006

17. Khaldi A, Helo N, Schneck MJ, Origitano TC: Venous thromboembolism: Deep venous thrombosis and pulmonary embolism in a neurosurgical population. J Neurosurg 114(1):40-46, 2011

18. Kim GH, Hahn DK, Kellner CP, Komotar RJ, Starke R, Garrett MC, Yao J, Cleveland J, Mayer SA, Connolly ES: The incidence of heparin-induced thrombocytopenia Type II in patients with subarachnoid hemorrhage treated with heparin versus enoxaparin. J Neurosurg 110(1):50-57, 2009

19. Kiphuth IC, Staykov D, Köhrmann M, Struffert T, Richter G, Bardutzky J, Kollmar R, Mäurer M, Schellinger PD, Hilz MJ, Doerfler A, Schwab S, Huttner HB: Early administration of low molecular weight heparin after spontaneous intracerebral hemorrhage. A safety analysis. Cerebrovasc Dis 27(2):146150, 2009

20. Leon L, Rodriguez H, Tawk RG, Ondra SL, Labropoulos N, Morasch MD: The prophylactic use of inferior vena cava filters in patients undergoing high-risk spinal surgery. Ann Vasc Surg 19:442-447, 2005

21. Macdonald RL, Amidei C, Baron J, Weir B, Brown F, Erickson RK, Hekmatpanah J, Frim D: Randomized, pilot study of intermittent pneumatic compression devices plus dalteparin versus intermittent pneumatic compression devices plus heparin for prevention of venous thromboembolism in patients undergoing craniotomy. Surg Neurol 59:363-372, 2003

22. McClendon J Jr, O'shaughnessy BA, Smith TR, Sugrue PA, Halpin RJ, Morasch M, Koski T, Ondra SL: Comprehensive assessment of prophylactic preoperative inferior vena cava filters for major spinal reconstruction in adults. Spine (PhilaPa 1976) 37(13):1122-1129, 2012

23. Mittal MK, Rabinstein AA: Anticoagulation-related intracranial hemorrhages. Curr Atheroscler Rep 14(4):351-359, 2012

24. Ozturk C, Ganiyusufoglu K, Alanay A, Aydogan M, Onat L, Hamzaoglu A: Efficacy of prophylactic placement of inferior vena cava filter in patients undergoing spinal surgery. Spine (PhilaPa 1976) 35(20):1893-1896, 2010

25. Papadimitiou K, Amin AG, Kretzer RM, Sciubba DM, Bydon A, Witham TF, Wolinsky JP, Gokaslan ZL, Baaj AA: Thromboembolic events and spinal surgery. J Clin Neurosci 19(12):1617-1621, 2012

26. PREPIC Study Group: Eight-year follow-up of patients with permanent vena cava filters in the prevention of pulmonary embolism: The PREPIC (Prevention du Risque d'Embolie Pulmonaire par Interruption Cave) randomized study. Circulation 112(3):416-422, 2005

27. Rajasekhar A, Streiff MB: Vena cava filters for management of venous thromboembolism: A clinical review. Blood Rev 27(5):225-241, 2013 
28. Rosner MK, KukloTR, Tawk R, Moquin R, Ondra SL: Prophylactic placement of an inferior vena cava filter in high-risk patients undergoing spinal reconstruction. Neurosurg Focus 17:E6, 2004

29. Semrad TJ, O'Donnell R, Wun T, Chew H, Harvey D, Zhou H, White $\mathrm{RH}$ : Epidemiology of venous thromboembolism in 9489 patients with malignant glioma. J Neurosurg 106(4): 601-608, 2007

30. Stein PD, Kayali F, Olson RE: Twenty-one-year trends in the use of inferior vena cava filters. Arch Intern Med 164:15411545,2004
31. Stein PD, Matta F, Hull RD: Increasing use of vena cava filters for prevention of pulmonary embolism. AM J Med 124: 655-661, 2011

32. Tanabe Y, Obayashi T, Yamamoto T, Nakata J, Yagi H, Takayama $M$, Nagao K: Current status of the use of inferior vena cava filters in cases of pulmonary embolism in CCUs: From the Tokyo CCU Network. J Cardiol 63(5):385-389, 2014

33. Zhou D, Spain J, Moon E, Mclennan G, Sands MJ, Wang W: Retrospective review of 120 celect inferior vena cava filter retrievals: Experience at a single institution. J Vasc Interv Radiol 23:1557-1563, 2012 